\title{
Entomological Survey of the Sand Fly Fauna of Kayseri Province: Focus on Visceral and Cutaneous Leishmaniasis in Central Anatolia, Turkey
}

\author{
Kayseri İlinin Kum Sineği Faunası Üzerine Entomolojik Çalışma: \\ Türkiye'nin Orta Anadolu Bölgesinnde Yeni Bir Kutanöz Leishmaniasis \\ Odağ
}

\author{
(1) Zeph Nelson Omondi ${ }^{1}$, (1) Samiye Demir ${ }^{1}$, (1) Suha Kenan Arserim ${ }^{2}$ \\ ${ }^{1}$ Ege University Faculty of Science, Department of Biology, İzmir, Turkey \\ ${ }^{2}$ Celal Bayar University, Vocational School of Health Sciences, Manisa, Turkey
}

Cite this article as: Omondi ZN, Demir S, Arserim SK. Entomological Survey of the Sand Fly Fauna of Kayseri Province: Focus on Visceral and Cutaneous Leishmaniasis in Central Anatolia, Turkey. Turkiye Parazitol Derg 2020;44(3):158-63.

\begin{abstract}
Objective: In Turkey, leishmaniasis occurs in two clinical forms: cutaneous leishmaniasis (CL) and visceral leishmaniasis (VL). CL has been reported mainly from south-eastern Anatolia and the eastern part of the Mediterranean region, whereas VL is sporadic in almost all geographical regions of Turkey. Both clinical forms of the disease have been recorded in Kayseri province for decades, but no study has been conducted on the sand fly fauna in this area. Therefore, we determine the species composition and population dynamics of sand flies prevalent in Kayseri province and identify possible vector species.

Methods: Data related to the recent locations of CL and VL cases were obtained from the Ministry of Health, and sand flies were collected in 14 localities of different districts using CDC light traps. The specimens were transferred to the laboratory in $70 \%$ ethanol, and morphological identification to the species level was performed using previously written keys.

Results: A total of 1,636 sand fly specimens were collected. Morphological identification revealed eight species of the genus Phlebotomus (P. perfiliewi s.l., P. halepensis, P. simici, P. major s.l., P. papatasi, P. tobbi, P. sergenti and P. mascittii) and one species of the genus Sergentomyia (S. dentata). Among all specimens, members of subgenus Adlerius (54.58\%) formed the dominant group, followed by the subgenus Larroussius (43.76\%).

Conclusion: Our results showed that $P$. halepensis, belonging to subgenus Adlerius, and P. perfiliewi, belonging to the subgenus, are probable vectors of cutaneous and VL in the province, respectively.
\end{abstract}

Keywords: Kayseri, sand fly, Leishmaniasis, Central Anatolia, Phlebotomus

ÖZ

Amaç: Türkiye'de leishmaniasis, kutanöz leishmaniasis (KL) ve visseral leishmaniasis (VL) olmak üzere iki klinik formda görülür. KL ağırlıklı olarak Türkiye'nin Güneydoğu Anadolu ve Akdeniz Bölgesi’nin doğusunda bildirilirken VL hemen hemen tüm coğrafi bölgelerinde sporadik olarak görülmektedir. Kayseri ilinde hastalığın her iki klinik şekli onlarca yıldır kaydedilmiştir ancak bu alanda kum sineği faunası üzerine bir çalışma bulunmamaktadır. Bu sebeple Kayseri ilinde yaygın olarak bulunan kum sineklerinin tür kompozisyonu, popülasyon dinamikleri ve olası vektör türlerinin belirlenmesi amaçlanmıştır.

Yöntemler: KL ve VL olgularının son zamanlarda görüldüğü yerlere ilişkin veriler Sağlık Bakanlığı’ndan alınmış ve CDC ışık tuzakları kullanılarak farklı ilçelerde 14 lokaliteden kum sineği örnekleri toplanmıştır. Örnekler \%70 etanol içinde laboratuvara getirilmiş ve türlerin morfolojik olarak teşhisleri mevcut teşhis anahtarları kullanılarak yapılmıştır.

Bulgular: Toplamda 1,636 kum sineği toplanmıştır. Morfolojik tür teşhisinde Phlebotomus cinsine ait sekiz tür (P. perfiliewi s.l, P. halepensis, P. simici, P. major s.l, P. papatasi, P. tobbi, P. sergenti ve P. mascittii) ve Sergentomyia cinsine ait bir tür (S. dentata) teşhis edilmiştir. Tespit edilen türler arasında Adlerius $(\% 54,58)$ alt cinsi üyeleri en baskın grubu oluşturken bunu Larroussius alt cinsi $(\% 43,76)$ izlemiştir.

Sonuç: Bu sonuçlara göre, ildeki kutanöz ve VL'nin muhtemel vektörleri sırasıyla Adlerius alt cinsine ait $P$. halepensis ve Larroussius alt cinsine ait P. perfiliewi olabilir.

Anahtar Kelimeler: Kayseri, kum sineği, Leishmaniasis, İç Anadolu, Phlebotomus 


\section{INTRODUCTION}

Phlebotomine sand flies (Diptera: Psychodidae) are the only proven vectors to transmit Leishmania parasites causing leishmaniasis. Approximately 1000 species of sand flies have been described in the Old and New Worlds $(1,2)$. However, less than a hundred species belonging to Phlebotomus and Lutzomyia genera are proven or suspected vectors of human leishmaniasis in Old and New Worlds respectively (3).

Leishmaniasis is one of the endemic infectious diseases in Turkey and two clinical forms are present; visceral leishmaniasis (VL) and cutaneous leishmaniasis (CL). CL became most important vectorborne disease in Turkey after the elimination of malaria. Around 2000 CL cases have been reported each year and 43, 600 new cases of CL were recorded between 1990 and 2010 (4). The influx of Syrian refugees has had significant effects on the epidemiology of CL in the south/southeastern part of Turkey $(5,6)$. Leishmania tropica is main causative agent of CL but the cases caused by $L$. infantum, L. major and $L$. donovani have also been reported in Turkey $(7,8)$. Ninety percent of $C L$ cases have been reported from 6 provinces located in Southeastern and Mediterranean Regions (9). Between 30 and 35 cases of VL caused by L. infantum are yearly reported from almost all geographical regions of Turkey (10).

There are currently 28 species of phlebotomine sand flies identified in Turkey (11). Phlebotomus tobbi (P. tobbi) is the only proven vector of $L$. infantum causing CL in Southern Anatolia $(12,13)$. Phlebotomus sergenti (P. sergenti) is probable vector of $L$. tropica in Southeastern Region $(14,15)$ while $P$. halepensis was also incriminated as probable vector species of $L$. tropica in Central Anatolia (16). In addition, Phlebotomus papatasi (P. papatasi) has been implicated as a potential vector in some parts of Turkey where CL cases due to L. major have been detected (8). The members of Larroussius subgenus such as $P$. tobbi and P. neglectus can transmit main causative agent, $L$. infantum (MON-1), causing human VL $(17,18)$.

Between 1995 and 2012, thirty six CL cases were reported from Yahyalı, Tomarza, İncesu, Develi, Melikgazi, Pınarbaşı and Akkışla districts in Kayseri province (19). In the same period, nine patients from Yahyal, Felahiye, and Melikgazi districts were diagnosed with VL (20). However, to the best of our knowledge, there is no published data on the sand fly fauna of the province except for a collection of six sand fly specimens in the year of 2007 (21). It is essential to have an accurate and updated record of sand fly population dynamics as a starting baseline of formulating policies to control leishmaniasis. Therefore, we aimed to investigate the sand fly fauna in Kayseri province in order to determine the species composition and population dynamics of sand flies and to identify possible vector species for both diseases in the province.

\section{MATERIALS AND METHODS}

Kayseri is located in the Central Anatolia Region, Turkey (44' 5.2872" N and $35^{\circ} 28^{\prime} 4.7532 " \mathrm{E}$ ) where the annual mean temperature is $10.6{ }^{\circ} \mathrm{C}$. January is the coldest month with average temperature of $-1.3^{\circ} \mathrm{C}$. August experiences the least amount of rain while April is the wettest month of the year.

Melikgazi, Hacılar, Kocasinan, Bünyan, Develi and Yahyalı districts were selected for sand fly collection according to the previous reports of CL cases obtained from Provincial Branch of Ministry of Health (Figure 1). Fourteen localities within these districts were then selected for sand fly sampling. Table 1 shows altitudes, average temperatures, humidity and coordinates of the sampling sites.

Between $16^{\text {th }}$ and $21^{\text {st }}$ of July 2018 a daily sand fly collection was carried out in different localities of the study area. Centers for disease control (CDC) miniature light traps were placed 1-2 meters above the ground and left on each site from 18:00 PM to 06:00 AM. The traps were collected the following morning and then the specimens were put into $70 \%$ ethanol using mouth aspirators. They kept in the ethanol until morphological examination was performed.

CDC light traps were placed in suitable habitats for sand flies such as sheep farms, poultry houses, dog shelters, cow sheds, outside of human shelters and abandoned shelters rich in organic material. At least one representative of the household was informed before the traps were set up. They were also informed about the operation procedure of the light traps to avoid interference during sampling. Characteristics of the localities such as temperature and humidity were recorded. These factors greatly influence sand fly distribution and sampling.

The specimens collected from each location were separated as males and females under stereo microscope (Olympus SZ40). Subsequently, the total number of sand flies and the number of males and females were determined. Head and the posterior part of the abdomen including genitalia and other decisive characters of males and females were dissected using thin needles. For light microscopy identification of male species, the head and genitalia are mounted on a glass slide and covered with Swan solution (11). For clear observation of spermatheca, the female dissected parts were covered with a mixture of Marc-André and Swan solutions. The relevant literature on identification of species, diagnosis keys and drawings were used for morphological identification of the specimens (22-27).

\section{Statistical Analysis}

Tables and picture were used to display data. No statistical tools were used.

\section{RESULTS}

A total of 1.636 sand flies, 203 males and 1.433 females, were sampled. The female to male ratio was 7.06 (Table 2). Eight species

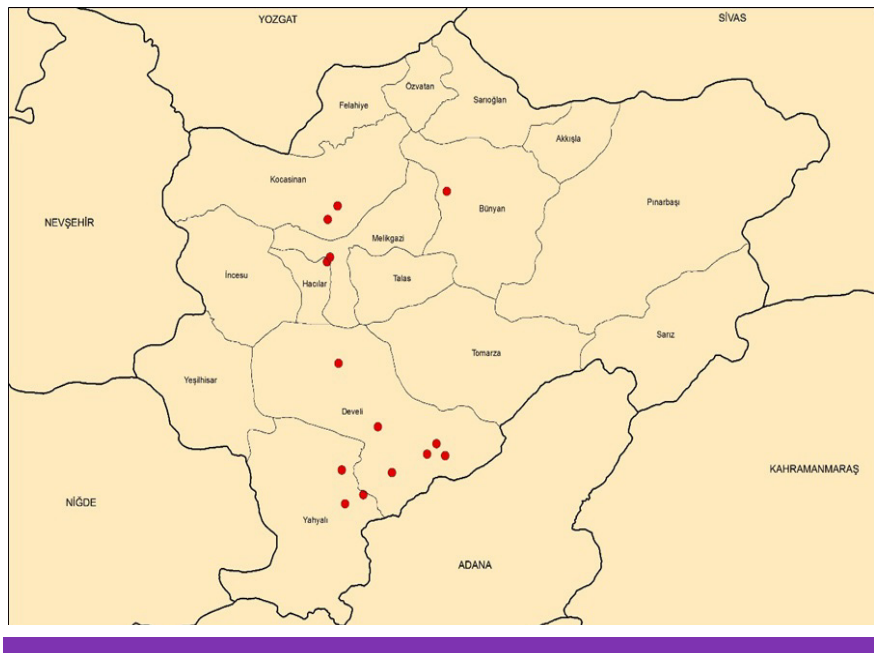

Figure 1. Map showing sampling localities in the study area 
of phlebotomine sand flies belonging to genus Phlebotomus (P. perfiliewi s.1. 40.40\%, P. halepensis 5.13\%, P. simici 3.06\%, P. major s.l. $3.06 \%$, P. papatasi $0.79 \%$, P. tobbi $0.06 \%$, P. sergenti $0.06 \%$ and
P. mascittii 0.06\%) and one species from genus Sergentomyia (S. dentate $0.55 \%$ ) were identified (Table 3 ). Since it's not possible to morphologically differentiate females of subgenus Adlerius, only

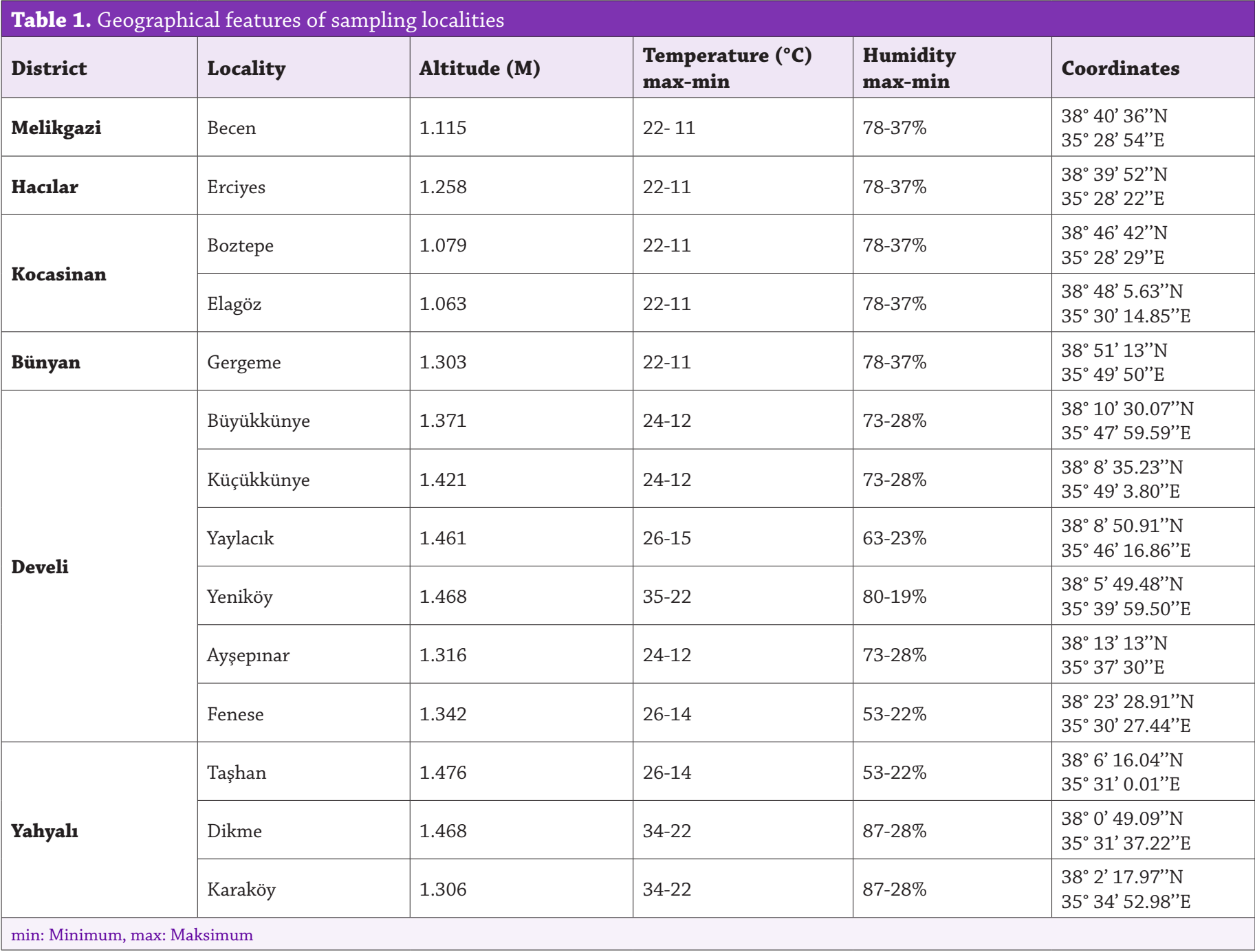

\section{Table 2. Species and numbers of sand flies collected in diverse areas of Kayseri province}

\begin{tabular}{|c|c|c|c|c|c|c|}
\hline Subgenus & Species & Female & Male & Total & $\begin{array}{l}\text { Female/male } \\
\text { ratio }\end{array}$ & $\begin{array}{l}\text { Degree of } \\
\text { presence \% }\end{array}$ \\
\hline \multirow{2}{*}{ Adlerius } & Adlerius sp. & 757 & 2 & 759 & 378.5 & 46.39 \\
\hline & P. simici & - & 50 & 50 & 0 & 3.06 \\
\hline \multirow{2}{*}{ Larroussius } & P. perfiliewi s.l. & 627 & 34 & 661 & 18.44 & 40.40 \\
\hline & P. tobbi & - & 1 & 1 & 0 & 0.06 \\
\hline Phlebotomus & P. papatasi & 5 & 8 & 13 & 0.625 & 0.79 \\
\hline Paraphlebotomus & P. sergenti & 1 & - & 1 & - & 0.06 \\
\hline Transphlebotomus & Transphlebotomus sp. & - & 2 & 2 & 0 & 0.12 \\
\hline Sergentomyia & Total & 1.433 & 203 & 1.636 & 7.06 & 100 \\
\hline
\end{tabular}




\begin{tabular}{|c|c|c|c|c|c|c|c|c|c|c|c|c|c|c|}
\hline $\begin{array}{l}\bar{\Xi} \\
\text { है }\end{array}$ & $\underset{\sim}{ت}$ & 0 & $\sim$ & $r$ & के & 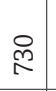 & $\tilde{\sigma}$ & \begin{tabular}{l|c}
\multirow{H}{0}{} \\
$\stackrel{n}{n}$
\end{tabular} & 6 in & 0 & 今ે & मे & 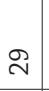 & $\begin{array}{l}\mathscr{0} \\
0 \\
\text { - }\end{array}$ \\
\hline 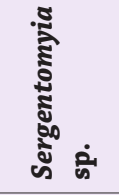 & . & ' & 1 & 1 & , & $r$ & 1 & ' & 1 & . & 1 & 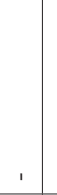 & . & -1 \\
\hline 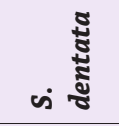 & . & 1 & 1 & ' & . & $\theta$ & 1 & ' & $\begin{array}{l}1 \\
1\end{array}$ & , & $\theta$ & ' & . & $\sigma$ \\
\hline 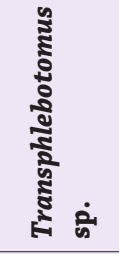 & . & ' & ' & ' & I & . & ' & $\sim$ & $\begin{array}{lll} & 1\end{array}$ & , & 1 & ' & I & . \\
\hline 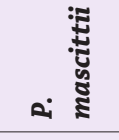 & ' & & ' & ' & . & -1 & & I & I & 1 & I & I & . & -1 \\
\hline م. & . & I & ' & ' & . & . & ' & ' & I & . & $r$ & , & . & -1 \\
\hline هi & ! & & ' & . & I & . & $N$ & $\rightarrow N$ & $\begin{array}{lll}v & -1 \\
\end{array}$ & , & 0 . & -1 & , & $\stackrel{m}{7}$ \\
\hline 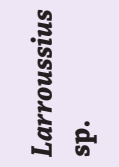 & , & ' & , & ' & . & -1 & -1 & 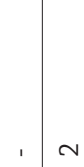 & v I & , & . & , & . & $\sigma$ \\
\hline 2: & . & & . & ' & . &. & 1 & . & $\begin{array}{l}1 \\
1\end{array}$ & . & $\neg$ & ' & . & -1 \\
\hline ه : & -1 & & I & . & I & $\infty$ & $\begin{array}{lll}N & 0\end{array}$ & $\infty \quad 1$ & $m$ & , & $\stackrel{9}{\sim}$ & -1 & -1 & in \\
\hline 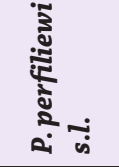 & 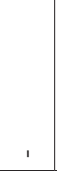 & & , & & m & $\stackrel{\substack{\infty \\
\sim}}{\sim}$ & $\underset{\sim}{\mathscr{T}}$ & in of & Pr & , & $\stackrel{\infty}{\sim}$ & $\stackrel{n}{n}$ & $\vec{\neg}$ & : \\
\hline 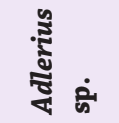 & $\sim$ & in & $N$ & , & -1 & 店 & $\approx$ & \begin{tabular}{l|l}
$\infty$ & $\infty$ \\
$\infty$
\end{tabular} & $\begin{array}{c}\Delta \\
\end{array}$ & in & $\underset{\sim}{m}$ & ما & $F$ & ผे \\
\hline 2. & 0 & $r$ & ' & $r$ & 1 & $\vec{m}$ & $\rightarrow 10$ & $m \quad \forall$ & +1 & , & I & $r$ & $\sim$ & in \\
\hline ن. & , & ' & , & 1 & . & $\stackrel{\infty}{\rightarrow}$ & $\stackrel{M}{\rightarrow}:$ & $\stackrel{m}{\rightarrow} \sim$ & $\begin{array}{l}v \\
\text { v }\end{array}$ & -1 & 号 & $\exists$ & -1 & $\Phi$ \\
\hline & 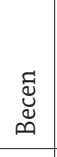 & 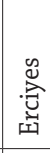 & $\mid$ & 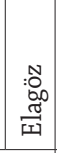 & 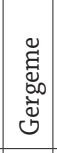 & 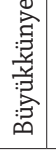 & 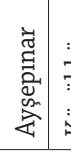 & 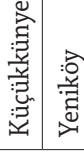 & 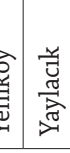 & 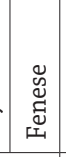 & 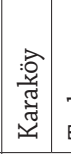 & 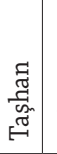 & 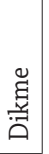 & \\
\hline & 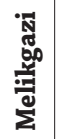 & 营 & & 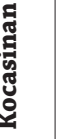 & 莡 & & & 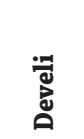 & & & & तี & & సేّ \\
\hline
\end{tabular}

males were identified. Females of this group were identified at the subgenus level. Four damaged specimens belonging to Larroussius and two Transphlebotomus could only be identified at subgenus level and one Sergentomyia specimen at genus level. Among males, $P$. halepensis was found to be the most dominant species. Among females Adlerius sp. which was recorded in 13 out of 14 sampling localities was the most dominant (Table 3).

\section{DISCUSSION}

This study presents the first report on sand fly fauna in Kayseri province, which is a focus especially for CL in Central Anatolia, Turkey. Eight Phlebotomus and one Sergentomyia species were detected in total. P. halepensis (Adlerius) and P. simici (Adlerius) and $P$. perfiliewi s.l (Larroussius) were recorded as dominant species in the province (Table 3 ).

Only male P. halepensis and P. simici specimens could be identified in our study since it is very difficult to morphologically differentiate females of subgenus Adlerius. As they are always identified with associated males, it can be deduced that female $P$. halepensis the most and P. simici is the second most dominant female species in Kayseri province (Table 2). Phlebotomus halepensis has previously been detected in Mediterranean Basin countries including Turkey (23). Kavur et al. (16) reported $P$. halepensis as dominant species in Niğde province in Central Anatolia. In the same study, $P$. halepensis was incriminated as a probable vector species of L. tropica in the region. In a study of distribution and altitude structuring of sand fly fauna in the Southern Anatolia, Şimşek et al. (21) reported $P$. halepensis as the only species in Kayseri province even though very few specimens identified. $P$. simici was also the second most dominant species (3.83\%) in a sand fly fauna study of a neighboring province, Niğde (16).

Adlerius species are competent vectors for Old World leishmaniasis across Europe and Asia. P. simici was found positive for Leishmania DNA in a VL focus in Greece (28) and the distribution of $P$. halepensis is reported to be in accordance with those of VL and CL. It was also reported to be highly susceptible to L. major and L. tropica with infection rates of $\sim 90 \%$ and $~ 80 \%$ respectively in a Vectorial Competency test (29).

P. perfiliewi s.l. is a species complex composed of P. perfiliewi, $P$. galilaeus and $P$. transcaucasicus $(30,31)$. Turkey is the only place where these three species were found in sympatry $(21,32,33)$. It is very difficult to differentiate female members of this group and morphological features of the male aedeagus differ according to the geographical origin. Molecular techniques are necessary for better identification of this species complex. P. perfiliewi is one of the main vectors of $L$. infantum in Mediterranean Basin and Central Asia (31). Oshaghi et al. (34) reported P. transcaucasicus as the main vector for $L$. donovani and $L$. infantum in the Northwest Iran. Şimşek et al. (21) recorded P. perfiliewi s.l. (P. perfiliewi $0.01 \%$, P. galilaeus $5.3 \%$ and P. transcaucasicus $13.3 \%$ ) in Southern Anatolia in Turkey. In a previous study from the region, no P. perfiliewi s.l. was reported (16).

Phlebotomus major s.l. comprises morphologically similar species (P. major, P. wui, P. notus, $P$. wenyoni, $P$. syriacus and $P$. neglectus) (30). P. syriacus and $P$. neglectus have been reported in western, northern and southern parts of Turkey $(33,35,36)$. In a recent study on sand fly fauna of Central Anatolia (Niğde Province) no P. major s.l. was reported (16). 
P. papatasi has been previously identified in various regions of Turkey $(33,37)$. In the present study area, 13 P. papatasi specimens were identified, representing $0.79 \%$ of the total collected sand flies. Only one specimen of P. tobbi, P. sergenti and P. mascittii were found in our study. This may be due to the small number of collected sand flies in some areas.

In previous studies of sand fly fauna in Turkey, Sergentomyia dentata has been reported in the Mediterranean Region of the country $(30,36,38)$. Şimsek et al. (21) and Kavur et al. (16) did not found any member of genus Sergentomyia in sand fly studies in Central Anatolia Region.

\section{CONCLUSION}

Our results showed that $P$. halepensis belonging to Adlerius subgenus and $P$. perfiliewi belonging to Larroussius subgenus can be probable vectors of cutaneous and VL in the province, respectively. This study will provide data in designing vector control strategies and epidemiological prediction models aiming to control CL and $\mathrm{VL}$ in this area. However, more studies are required to confirm the suspected species' vectorial status. In addition, use of molecular markers in identification of species especially among females of subgenus Adlerius and Larroussius are needed.

\section{ACKNOWLEDGEMENT}

We gratefully acknowledge Prof. Yusuf Özbel for logistics assistance and suggestions during the study, Dr. Özge Erişöz Kasap and Kardelen Yetişmiş for assistance in the field and Prof. Dr. Kirami Olgen from Ege University Department of Geography for preparing the map.

\section{* Ethics}

Ethics Committee Approval: Not applicable. Our work involved sand flies from the wild. No patients or animals were involved in the study. Therefore, we had no ethics committee and approval number.

Informed Consent: Not applicable. Our work involved sand flies from the wild. No patients or animals were involved in the study.

Peer-review: Internally peer-reviewed.

\section{* Authorship Contributions}

Concept: Z.N.O., S.D., S.K.A., Design: Z.N.O., S.D., Data Collection or Processing: Z.N.O., S.K.A., Analysis or Interpretation: Z.N.O., S.D., S.K.A., Literature Search: Z.N.O., S.D., Writing: Z.N.O., S.D., S.K.A.

Conflict of Interest: No conflict of interest was declared by the authors.

Financial Disclosure: This study was supported by The Scientific and Technical Research Council of Turkey (TÜBİTAK) project no: 114 S999.

\section{REFERENCES}

1. Ready DP. Biology of Phlebotomine Sand Flies as Vectors of Disease Agents. Annu Rev Entomol 2013; 58: 227-50.

2. Bates P, Depaquit J, Galati E, Kamhawi S, Maroli M, McDowell M, et al. Recent advances in phlebotomine sand fly research related to leishmaniasis control. Parasites Vectors 2015; 8: 131.
3. Maroli M, Feliciangeli M, Bichaud L, Charrel R, Gradoni L. Phlebotomine sandflies and the spreading of leishmaniases and other diseases of public health concern. Medical and Veterinary Entomology 2012; 27: 123-47.

4. Gürel MS, Yeşilova Y, Ölgen MK, Özbel Y. Cutaneous Leishmaniasis in Turkey. Turkiye Parazitol Derg 2012; 36: 121-9.

5. İnci R Ozturk P, Mulayim M, Ozyurt K, Alatas ET, İnci MF. Effect of the Syrian Civil War on Prevalence of Cutaneous Leishmaniasis in Southeastern Anatolia, Turkey. Medical Science Monitor 2015; 21: 21004.

6. Özkeklikçi A, Karakuş M, Özbel Y, Töz S. The new situation of cutaneous leishmaniasis after Syrian civil war in Gaziantep city, Southeastern region of Turkey. Acta Tropica 2017; 166: 35-8.

7. Özbilgin A, Harman M, Karakuş M, Bart A, Töz S, Kurt Ö, et al. Leishmaniasis in Turkey: Visceral and cutaneous leishmaniasis caused by Leishmania donovani in Turkey. Acta Tropica 2017; 173: 90-6.

8. Özbilgin A, Çulha G, Uzun S, Harman M, Topal SG, Okudan F, et al. Leishmaniasis in Turkey: first clinical isolation of Leishmania major from 18 autochthonous cases of cutaneous leishmaniasis in four geographical regions. Trop Med Int Health 2016; 21: 783-91.

9. Özbilgin A, Töz S, Harman M, Topal SG, Uzun S, Okudan F, et al. The current clinical and geographical situation of cutaneous leishmaniasis based on species identification in Turkey. Acta Tropica 2019; 190: 59-67.

10. Gradoni L, Lopez- R, Mokni M. Manual on case management and surveillance of the leishmaniases in the Who European region. Copenhagen: World Health Organization Regional Office for Europe. World Health Organization. 2017. Retrieved from: http://www.euro. who.int/_data/assets/pdf file/0006/341970/MANUAL-ON-CASEMANAGEMENT_FINAL_with-cover-and-ISBN.pdf

11. Arserim SK, Çetin H, Töz S, Özbel Y. Kum Sinekleri (Diptera: Psychodidae) Vektörlükleri Ve Mücadelesi. In Y. Özbel, Vektör Artropodlarve Mücadelesi. Yayın No: 25. Izmir: Türkiye Parazitoloji Derneği; 2017.p.123-99.

12. Svobodová M, Alten B, Zídková L, Dvořák V, Hlavačková J, Myšková J, et al. Cutaneous leishmaniasis caused by Leishmania infantum transmitted by Phlebotomus tobbi. Turkiye Parazitol Derg 2009; 39: 251-6.

13. Özbel Y, Karakuş M, Arserim SK, Kalkan Ş, Töz S. Molecular detection and identification of Leishmania spp. in naturally infected Phlebotomus tobbi and Sergentomyia dentata in a focus of human and canine leishmaniasis in western Turkey. Acta Tropica 2016; 155: 89-94.

14. Volf P, Ozbel Y, Akkafa F, Svobodová M, Votýpka J, Chang K. Sand Flies (Diptera: Phlebotominae) in Şanliurfa, Turkey: Relationship of Phlebotomus sergenti with the Epidemic of Anthroponotic Cutaneous Leishmaniasis. J Med Entomol 2002; 39: 12-5.

15. Demir S, Karakus M. Natural Leishmania infection of Phlebotomus sergenti (Diptera: Phlebotominae) in an endemic focus of cutaneous leishmaniasis in Şanliurfa, Turkey. Acta Tropica 2015; 149: 45-8.

16. Kavur H, Arıkan H, Özbel Y. Phlebotomus halepensis (Diptera: Psychodidae) Vectorial Capacity in Afyon and Nigde Province, Turkey. J Med Entomol 2017; 55: 317-22

17. Léger N, Depaquit J, Ferté H, Rioux J, Gantier J, Gramiccia M, et al. Les phlébotomes (Diptera-Psychodidae) de l'île de Chypre.II - Presence de Leishmania (Leishmania) infantum Nicolle, 1908 (zymodeme MON 1) chez Phlebotomus (Larroussius) tobbi Adler et Theodor, 1930. Parasite 2000; 7: 143-6.

18. Velo E, Bongiorno G, Kadriaj P, Myrseli T, Crilly J, Lika A, et al. The current status of phlebotomine sand flies in Albania and incrimination of Phlebotomus neglectus (Diptera, Psychodidae) as the main vector of Leishmania infantum. PLOS ONE 2017; 12: e0179118.

19. Yazar S, Kuk S, Cetinkaya U, Sahin I. Leishmania sp. in Cutaneous Leishmaniasis suspected patients is Kayseri. Ankara Üniversitesi Veteriner Fakültesi Derg 2013; 60: 177-8.

20. Yazar S, Kuk S, Cetinkaya U, Uyar Y, Sahin I. Leishmania sp. in Visceral Leishmaniasis suspected patients in Kayseri. Ankara Üniversitesi Veteriner Fakültesi Derg 2013; 60: 185-7. 
21. Şimşek F, Alten B, Caglar S, Ozbel Y, Aytekin A, Kaynas S, et al. Distribution and altitudinal structuring of phlebotomine sand flies (Diptera: Psychodidae) in southern Anatolia, Turkey: their relation to human cutaneous leishmaniasis. J Vector Ecol 2007; 32: 269-79.

22. Lewis DJ. Phlebotomine sandflies (Diptera: Psychodidae) from the Oriental Region. Bulletin of the British Museum (Natural History) B. Entomology 1978; 37: 217-343.

23. Lewis DJ. A taxonomic review of the genus Phlebotomus (Diptera: Psychodidae). Bulletin of the British Museum (Natural History) Entomology Series 1982; 52: 1-35.

24. Perfil'ev, P.P. Phlebotomidae (sand flies). In: Theodor O. (ed.) Fauna of USSR. Acad Sci USSR (English Translation by Israel Programme for Scientific Translations, Jerusalem 1968.p.1-362.

25. Lane RP. Sand Flies (Phlebotomidae) In: RP Lane \& RW Crosskey (eds.): Medical Insect and Arachnids. Chapman- Hall: London; 1993.p.78-119.

26. Artemiev MM, Neronov VM. Distribution and Ecology of Sandflies of the Old World (Genus: Phlebotomus), Institute of Evolution, Morphology and Animal Ecologym USSR: Moscow; 1984.p.208

27. Depaquit J, Léger N, Ferté H, Rioux J, Gantier J, Michaelides A, et al. Les phlébotomes de l'Île de Chypre III - Inventairefaunistique. Parasite 2001; 8: 11-20.

28. Aransay AM, Scoulica E, Tselentis Y. Detection and identification of Leishmania DNA within naturally infected sand flies by semi-nested PCR on minicircle. Appl Environ Microbiol 2000; 66: 1933-8.

29. Sádlová J, Hajmova M, Volf P. Phlebotomus (Adlerius) halepensis vector competence for Leishmania major and Le. tropica. Med Vet Entomol 2003; 17: 244-50.

30. Erişöz Kasap O, Linton Y, Karakuş M, Ozbel Y, Alten B. Revision of the species composition and distribution of Turkish sand flies using DNA barcodes. Parasites Vectors 2019; 12: 1-20.
31. Depaquit J, Bounamous A, Akhoundi M, Augot D, Sauvage F, Dvorak V, et al. A taxonomic study of Phlebotomus (Larroussius) perfiliewi s. l. Infection Genet Evol 2013; 20: 500-8.

32. Sari B, Limoncu ME, Balcıoğlu IC, Aldemir A, Tasci GT, Kiliç Y, et al. Seroepidemiological and entomological survey in a new focus of zoonotic visceral leishmaniasis in Kars Province, Northeastern Turkey. Vet Parasitol 2015; 209: 179-87.

33. Özbel Y, Balcioğlu I, Ölgen M, Şimşek F, Töz S, Ertabaklar H, et al. Spatial distribution of phlebotomine sand flies in the Aydin Mountains and surroundings: the main focus of cutaneous leishmaniasis in western Turkey. J Vector Ecol 2011; 36: 99-105.

34. Oshaghi MA, Ravasan NM, Hide M, Javadian EA, Rassi Y, Sadraei J, et al. Phlebotomus perfiliewi transcaucasicus is circulating both Leishmania donovani and L. infantum in northwest Iran. Exp Parasitol 2009; 123: 21825.

35. Kasap OE, Votýpka J, Alten B. The distribution of the Phlebotomus major complex (Diptera: Psychodidae) in Turkey. Acta Tropica 2013; 127: 20411.

36. Kavur H, Eroglu F, Evyapan G, Demirkazik M, Alptekin D, Koltaş I. Entomological Survey for Sand Fly Fauna in Imamoglu Province (Cutaneous Leishmaniasis Endemic Region) of Adana, Turkey. J Med Entomol 2015; 52: 813-8.

37. Belen A, Alten B. Seasonal dynamics and altitudinal distributions of sand fly (Diptera: Psychodidae) populations in a cutaneous leishmaniasis endemic area of the Cukurova region of Turkey. J Vector Ecol 2011; 36(Suppl 1): 87-94.

38. Yaman M, Özbel Y. The sandflies (Diptera: Psychodidae) in the Turkish province of Hatay: some possible vectors of the parasites causing human cutaneous leishmaniasis. Ann Trop Med Parasitol 2004; 98: 741-50. 